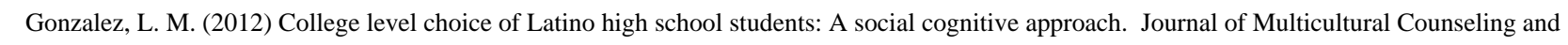
Development,40, 3, 144-155. doi/10.1002/j.2161-1912.2012.00014

Reprinted from Journal of Multicultural Counseling and Development 40, 3, 144-155 (C) 2012 The American Counseling Association. Reprinted with permission. No further reproduction authorized with out written permission from the American Counseling Association

Received 03/29/11

Revised 10/01/11

Accepted 10/29/11

\title{
College-Level Choice of Latino High School Students: A Social-Cognitive Approach
}

\begin{abstract}
Laura M. Gonzalez
Latino students attend 2-year colleges more often than 4-year colleges. This has an impact on the rate of bachelor's degree attainment, because the transfer rate between the 2 levels is low. The author uses national data to identify predictors associated with college-level choice and then uses social-cognitive career theory (Lent, Brown, \& Hackett, 1994) to frame counseling implications.

Keywords: Latino students, college-level choice

Los estudiantes Latinos se matriculan con más frecuencia en estudios universitarios de 2 años que en estudios de 4 años. Esto produce un impacto en el porcentaje de obtención de licenciaturas, porque la tasa de transferencia entre ambos niveles es baja. El autor emplea datos a nivel nacional para identificar predictores asociados con la elección del nivel de estudios universitarios, y después emplea la teoría social cognitiva de las carreras (Lent, Brown, \& Hackett, 1994) para formular las implicaciones para la consejería.
\end{abstract}

Palabras clave: Estudiantes Latinos, elección del nivel de estudios universitarios

$\sim$ ollege choice is more than just a decision made in adolescence; it is a developmental transition built on a foundation of early experiences within schools, families, and communities. College choice has a powerful impact on future identity, career development, social and economic opportunity, and fulfillment of aspirations (Perna, 2005). The choices disenfranchised individuals and groups make about higher education have important implications that can include future access to social capital, defined in the Bourdieuian tradition as networks that can improve one's access to information and resources (McDonough \& Nunez, 2007). Educational progress is an issue ripe for social advocacy and, thus, relevant to the counseling profession. One such issue involves the choice between 2-year and 4-year colleges.

National data demonstrate that Latinos are the only racial/ethnic group in the United States who enroll in 2-year colleges at higher rates than they do in 4-year colleges. Among college-going students, $60.6 \%$ of African Americans and $63.2 \%$ of Asian Americans selected 4-year universities in 2008, whereas

Laura M. Gonzalez, Department of Counseling and Educational Development, University of North Carolina at Greensboro. This research was supported by a grant from the American Educational Research Association (AERA), which receives funds for its AERA Grants Program from the National Science Foundation (NSF) and the National Center for Education Statistics of the Institute of Education Sciences (U.S. Department of Education) under NSF Grant REC-0310268. Opinions reflect those of the author and do not necessarily reflect those of the granting agencies. The author also wishes to thank Stanley Baker, DiAnne Borders, and Raymond Ting for their assistance. Correspondence concerning this article should be addressed to Laura M. Gonzalez, Department of Counseling and Educational Development, University of North Carolina at Greensboro, PO Box 26170, Greensboro, NC 27402 (e-mail: LMGONZA2@uncg.edu).

(C) 2012 American Counseling Association. All rights reserved. 
only $48.1 \%$ of Latinos made this choice, with the remaining $51.9 \%$ attending 2-year colleges (Aud, Fox, \& Kewal Ramani, 2010). Even when one controls for socioeconomic status (SES), degree intention, prior academic achievement, and location in proximity to community college, Latinos still make the decision to attend 2-year colleges more frequently than do other college-going students (Kurlaender, 2006). The purpose of this study is to explore potential influences on Latino high school students' college choice. Previous researchers have focused mostly on nonpsychological factors (e.g., demographic and academic explanations) for the high rate of community college utilization by Latinos (Kurlaender, 2006; O'Connor, 2009). These factors are not fully satisfactory for reasons that are explored momentarily.

Community colleges can provide a meaningful education for individuals who are well matched with the campus in terms of goals, needs, and available programs. The debate as to whether community colleges have a "democratization" effect that expands access or a "diversion" effect that limits successful degree completion is ongoing (Gonzalez \& Hilmer, 2006, p. 250). However, studies show that approximately $74 \%$ of students in associate's programs expressed an interest in a further degree and wanted to transfer to a 4-year university (Suarez, 2003). For those students, however, the multiple access and transition points from kindergarten to Grade 12 to a 2-year and then a 4-year college could slow or derail their momentum toward their goal (Baker \& Vélez, 1996). Indeed, the rate of transfer from a 2-year to a 4-year college for Latinos nationally is between $9 \%$ and 13\% (Bailey, Jenkins, \& Leinbach, 2005).

\section{demographic and academic factors}

Demographic factors suggested in the literature as having a relationship to college choice for Latinos include SES, generation of immigration, educational legacy in the family, and language proficiency (Bailey et al., 2005; Bohon, Macpherson, \& Atiles, 2005; Duran, 1983; Fry, 2002; Hagy \& Staniec, 2002; Kurlaender, 2006; Swail, Cabrera, \& Lee, 2004). Often poorly "resourced" schools are concomitant with impoverished neighborhoods or marginalized communities, so it may be difficult to separate the effects (Adelman, 2006; Contreras, 2005; Llagas \& Snyder, 2003; Swail et al., 2004).

Financial constraints are important to acknowledge, but income may not function as expected with Latino students. National census data show that African American and Latino families are similar in terms of mean income (in 2008, \$53,196 for African American households and \$54,145 for Latino households; U.S. Census Bureau, 2011). Yet national estimates are that $25 \%$ to $38 \%$ (depending on age range) of both European American and African American undergraduate students enroll initially in community colleges, whereas $40 \%$ to $55 \%$ of Latino undergraduate students do so (Bailey et al., 2005; Fry, 2002). O'Connor (2009) found that whereas low-SES students (Latino, European American, and African American) had similar tendencies 
to select community colleges over baccalaureate colleges, higher SES Latinos were much more likely to attend 2-year colleges (40\%) than were European Americans and African Americans (10\%).

Additionally, not all Latinos are first-generation immigrants; only $11 \%$ of children younger than 18 years are foreign born (Fry \& Passel, 2009). Bohon, Johnson, and Gorman (2006) found that strong college aspirations exist for students of Mexican, Cuban, and Puerto Rican descent, although the aspirations are moderated differently for each group by family SES, parental education, immigrant generation, and language spoken at home. Fry (2002) indicated that Latino first-generation immigrants attended college at a lower rate $(25 \%)$ than did subsequent generations, which contrasted with the experiences of Asian immigrants, who had high rates of college attendance $(58 \%)$ across both first and second generations. Thus, within and across groups, immigrants have differing experiences with postsecondary education.

Taken together, these studies suggest that SES and immigrant status do not fully explain the educational choices made by Latinos in the United States. Certainly, undocumented students living in poverty have very difficult circumstances and a low rate of college attendance (Perez, 2010). Researchers have posited that a strong social network could create chain migration to community colleges, with Latinos attending because of the presence of their friends and family (Perez \& McDonough, 2008; Person \& Rosenbaum, 2006).

Another theme in the literature is that Latinos go to community colleges because they lack academic preparation. Although school-age Latinos have had lower reading and math scores compared with other students, they have been making steady gains in terms of grade point averages, standardized test scores, and high school credits earned (Llagas \& Snyder, 2003). However, academic credentials that make one eligible for a 4-year college do not automatically lead to enrollment. The National Education Longitudinal Study (NELS:88; National Center for Education Statistics [NCES], n.d.-b) data showed that "almost 40 percent of Latino students considered worthy academically for four-year studies failed to enroll at a four-year institution" (Swail et al., 2004, p. 18). Kurlaender (2006) was able to demonstrate that Latinos scoring close to $100 \%$ on the NELS:88 math achievement test still had a $40 \%$ to $50 \%$ probability of choosing a 2-year over a 4-year college, compared with less than a $10 \%$ rate for African Americans and European Americans. Furthermore, other researchers have found that high-achieving Latinos in high school are the least likely of all racial/ethnic groups to complete a college application (Hurtado, Inkelas, Briggs, \& Rhee, 1997; Swail et al., 2004).

\section{social-cognitive approach}

Having argued that prior research and reports have not given a fully satisfactory explanation, the current research advances a different way to examine 
the educational choices of Latinos-through a social-cognitive lens. Socialcognitive career theory (SCCT; Lent, Brown, \& Hackett, 1994) originally addressed career choices, but educational choices are a logical direction to apply the framework. SCCT is an appropriate foundation for this study in that it includes constructs related to individuals and their social context, learning experiences and how individuals internalize them (i.e., formation of self-efficacy beliefs and outcome expectations for tasks), development of educational or career interests, and the resultant choices and goal-directed behavior. For example, a child with no college role models in his or her family (a restricted learning experience) has fewer people to ask for advice about how to prepare for the Scholastic Assessment Test (SAT) and may develop inaccurate outcome expectations.

These interpretations are important for counselors, because they represent a place to help students reframe their experiences, gain corrective learning opportunities, observe similar role models having success with the task, and so on. This motivational state then influences whether educational interests develop and the subsequent goals, choices, and actions that may be enacted (e.g., registering for an SAT prep course). Indeed, SCCT has been found useful to examine postsecondary goals and educational aspirations with Latinos in prior research (Flores, Navarro, \& DeWitz, 2008; Flores \& O’Brien, 2002; Flores, Ojeda, Huang, Gee, \& Lee, 2006; Gushue, Clarke, Pantzer, \& Scanlan, 2006; Ojeda \& Flores, 2008).

A few prior studies have explored the role of expectations or aspirations for college in Latinos (Behnke, Piercy, \& Diversi, 2004; Ceja, 2004; Goldsmith, 2004; Kao \& Tienda, 1998; Plunkett \& Bámaca-Gómez, 2003; St-Hilaire, 2002), but none have used SCCT specifically to examine college choice. Although the findings are mixed on how useful expectations are in terms of actual attainment, the literature does support some relationship between aspirations/ expectations and movement toward desired educational outcomes. Another recent study using SCCT examined the college-going plans of middle school students, some of whom were Latino, but all of whom would be first-generation college students (Gibbons \& Borders, 2010). The SCCT model was partially supported, with direct relationships from positive and negative outcome expectations and college-going self-efficacy beliefs to the studied outcome, intention to attend college. The present study goes a step further in examining college choice by using actual college enrollment as the outcome.

Thus, in the current study, I examine and control for previously identified variables, such as SES, language spoken at home, and academic profile, while including the more psychologically oriented variables of outcome expectations and self-efficacy beliefs that are suggested by SCCT. The study addressed the following research question: "How do SCCT-derived variables predict whether Latino high school students will enroll in a 2-year college or a 4-year college?" 


\section{method}

\section{PARTICIPANTS}

The participant data in this research came from the Education Longitudinal Study (ELS:2002), a survey by NCES (n.d.-a) that began with a school-based sample of 10th-grade students in 2002 and followed them through 2004, 2006, and beyond. ELS:2002 participants who were not Latino or who had not entered a 2-year or 4-year college were logically excluded. The final data set contained 685 Latino students (299 male, 386 female). Of the sample, $76 \%$ were born in the United States and 54\% spoke English as their first language. Family SES quartiles were not normally distributed, with $36 \%$ in the first (or lowest) quartile, $19 \%$ in the second quartile, $22 \%$ in the third quartile, and $22 \%$ in the fourth (or highest) quartile. In terms of the school environment, $48 \%$ of the students attended schools where $0 \%$ to $20 \%$ of the student population enrolled in free and reduced-price lunch programs, and $42 \%$ attended schools where $31 \%$ to $100 \%$ of the students received this aid. For descriptive purposes, $65 \%$ of those self-identifying as Latino in the 2004 data set stated that they were of Mexican or Mexican American origin. Other origins included Cuban (4\%), Dominican (4\%), Puerto Rican (13\%), Central American (7\%), and South American $(8 \%$; J. Wirt, personal communication, September 12, 2006).

\section{DATABASE DESCRIPTION}

Full details on the ELS:2002 survey are available in the manual (Ingels et al., 2004). The student questionnaire was the source for the majority of the variables in the present study. In addition to a math/language test, it includes "background, school experiences and activities, plans and goals for the future, employment and out-of-school experiences, language background, and psychological orientation toward learning" (Ingels et al., 2004, p. 12). The academic self-efficacy questions used in the ELS:2002 were adapted from the Program for International Student Assessment (Adams \& Wu, 2002). The questions are as follows: (a) "When I try to learn something really hard, I can do it"; (b) "I can learn something well if I want"; (c) "I'm confident I can do an excellent job on my English assignment"; and (d) "I'm certain I can understand the most difficult material presented in math texts."

The 24 variables used in the current study were chosen by (a) listing seven categories represented in the SCCT model and their original definitions, (b) accounting for the previously studied demographic and academic variables, and (c) consulting the list of variables available in the ELS:2002 database. The SCCT-derived variables are as follows: (a) person-related variables (English as native language, gender), (b) background contextual variables (family SES, country of student's birth, percentage of free and reduced-price lunch programs at the high school), (c) learning experiences (highest level of high 
school math, ELS:2002 achievement test quartiles, academic or vocational track in high school), (d) academic self-efficacy beliefs (five items as described previously), (e) outcome expectations (student's expectations for highest educational attainment), (f) interests/goals/actions (discussed going to college with parents; plan to attend college immediately after high school; plan to take SAT/American College Test [ACT]; important factors in college choice, including low expenses, living at home, academic reputation of college, easy admissions, and curriculum), and ( $\mathrm{g}$ ) proximal context (teacher and parent expectations for student's educational attainment).

\section{DATA ANALYSIS}

The outcome of interest - the level of the first postsecondary institution entered by the student-was coded as categorical $(0,1)$. Binary outcomes require a logistic regression analysis (Pampel, 2000). The analysis began with selecting predictor and outcome variables, along with design variables, such as strata, cluster, and weights, from the ELS:2002 through the online Education Data Analysis Tool (available at www.nces.ed.gov). Missing data were addressed with multiple imputation, a regression-based approach that predicts values for absent items on the basis of the values of present items (Allison, 2002).

I chose to dismiss cases that were missing because of survey instructions to logically skip items that did not apply—or responses such as "don't know"-but used imputation to reconstruct missing data due to partial interviews, multiple responses, some of the items with only one collection year present, and the truly missing data. Software packages used in this process included SAS 9.1.3 (for multiple imputation) and AM (American Institutes for Research, n.d.; for logistic regression with complex weighted samples). Multicollinearity was checked but was not present. Logistic regression findings are presented in terms of the odds that the outcome is affected by the variable of interest (Pampel, 2000).

\section{results}

The regression analysis addressed the main effect of each variable on all participants, while the other predictors were held constant. As shown in Table 1, the five coefficients that reached the level of significance $(p<.05)$ have a double asterisk, and the table note contains the calculated odds of that predictor's effect on the outcome. One variable bordered on significance $(p<.0505)$, as noted by one asterisk. The two significant variables associated with enrolling in a 2-year college were living at home and easy admissions as important factors in college choice. The four significant variables associated with the baseline variable of enrolling in a 4-year college were highest level of high school math, planning to or having taken the SAT/ACT, the student's expectations for highest educational attainment, and (bordering on significant) how often they discussed going to college with their parents. 


\section{TABLE 1}

\section{Logistic Regression Results for Study Variables}

\begin{tabular}{|c|c|c|c|c|}
\hline Variable & RE & $S E$ & $t$ & $p$ \\
\hline Intercept & 5.67 & 1.13 & 5.03 & $<.001$ \\
\hline Academic program in high school & -0.46 & 0.29 & -1.61 & .107 \\
\hline Vocational program in high school & -0.30 & 0.43 & -0.71 & .478 \\
\hline Highest high school matha & $-0.45^{\star *}$ & 0.18 & -2.56 & .011 \\
\hline Plans to take SAT/ACT ${ }^{\mathrm{b}}$ & $-1.32^{\star \star}$ & 0.51 & -2.60 & .009 \\
\hline Low expenses important factor & 0.02 & 0.21 & 0.12 & .908 \\
\hline Curriculum important factor & 0.16 & 0.22 & 0.73 & .466 \\
\hline Living at home important factor & $0.56^{* *}$ & 0.16 & 3.59 & .001 \\
\hline Academic reputation important factor & -0.33 & 0.19 & -1.73 & .084 \\
\hline Easy admissions important factor ${ }^{\mathrm{d}}$ & $0.76^{\star \star}$ & 0.19 & 4.02 & $<.001$ \\
\hline Student's expectations for attainment ${ }^{e}$ & $-0.48^{\star \star}$ & 0.14 & -3.38 & .001 \\
\hline Gender & -0.29 & 0.26 & -1.11 & .266 \\
\hline First language English & -0.45 & 0.27 & -1.68 & .094 \\
\hline Parent's aspirations for student & -0.01 & 0.14 & -0.05 & .962 \\
\hline English as a second language test score quartiles & 0.00 & 0.16 & -0.01 & .989 \\
\hline Family SES quartiles & -0.02 & 0.13 & -0.18 & .856 \\
\hline Student born in U.S. or not & 0.56 & 0.31 & 1.80 & .073 \\
\hline Percentage free lunch program at high school & -0.01 & 0.09 & -0.11 & .911 \\
\hline Discussed going to college with parents ${ }^{\dagger}$ & $-0.40^{*}$ & 0.20 & -1.96 & .0505 \\
\hline Teacher expectations for the student & -0.17 & 0.11 & -1.59 & .112 \\
\hline Can do difficult math problems & -0.19 & 0.17 & -1.15 & .254 \\
\hline Can learn something hard & 0.28 & 0.18 & 1.56 & .122 \\
\hline Can do well on English assignments & 0.03 & 0.22 & 0.12 & .906 \\
\hline Keep studying difficult material & -0.15 & 0.19 & -0.78 & .44 \\
\hline Can learn things well & -0.11 & 0.18 & -0.62 & .535 \\
\hline
\end{tabular}

Note. $\mathrm{RE}=$ regression estimate; SAT = Scholastic Assessment Test; $\mathrm{ACT}=$ American College Test; SES = socioeconomic status.

${ }^{\mathrm{a}}$ Odds of 4-year college $=1.6$. ${ }^{\mathrm{b}}$ Odds of 4 -year college $=3.7$. ${ }^{\mathrm{c}}$ Odds of 2 -year college $=1.8$. ${ }^{\mathrm{d}}$ Odds of 2-year college $=2.1$. ${ }^{\mathrm{e}}$ Odds of 4 -year college $=1.6 .{ }^{\mathrm{f}}$ Odds of 4 -year college $=1.5$. ${ }^{*} p<.0505 .{ }^{* *} p<.05$.

For every incremental change in the level of the predictor variable, there would be a related change in the odds of the outcome; for example, with each increase in the level of math completed in high school, there would be a 1.6 increase in the odds that students would attend a 4-year college (see Table 1). The ELS:2002 survey includes six possible responses for level of math, so the difference between the lowest level (basic math) and the highest level (trigonometry, precalculus, or calculus) would be a 9.6 increase in the odds of attending a 4-year college. Planning to take the SAT was the predictor with the highest impact on the odds that a student would attend a 4-year college (per unit increase), and valuing easy admissions standards was the predictor with the highest impact on the odds that a student would attend a 2-year college.

\section{discussion}

The goal of this research was to examine the decisions being made by many Latino students to begin their postsecondary education in 2-year colleges 
rather than 4-year colleges. Predictors found to be associated with 2-year college choice were statements of preference about institutional characteristics (distance and admissions standards). Predictors associated with 4-year college choice were a combination of aspirations, planning behaviors, and math level completion. In terms of SCCT, factors that could have an impact on choosing a 4-year college came from the parts of the model labeled learning experiences, outcome expectations, and interests/goals/actions. Hence, encouraging students to prepare for bachelor's degrees would mean addressing those categories.

The significant variables associated with attending a 4-year college were all areas in which counselors and teachers can provide assistance. First, counselors can encourage students to persist through the necessary testing (SAT/ACT) and course work to become college eligible and can help them understand the long-term consequences of decisions made in middle school (such as selection of math). This is especially important in families without a legacy of college attendance, where parents are often strong emotional supporters of their children's educational goals but may be less able to provide instrumental support to navigate the college admissions process (Zarate, 2007). Counselors who accept an advocacy role with historically underrepresented populations and college access must work to reverse limiting policies and practices in their settings as well as limiting beliefs among students (Goodman \& West-Olatunji, 2010). SCCT suggests that successful completion of a challenging learning experience (such as college preparatory math courses) can build positive self-beliefs and outcome expectations, which then increase the likelihood of students setting higher educational goals and engaging actively in the planning process.

Second, counselors and educators can engender predisposition to college by encouraging high expectations for all students and frequent discussions with parents (the borderline significant variable). The lack of similar role models, messages about low expectations, and fewer opportunities for parental involvement can interfere with the important work of empowering all students to envision educational success and maximize their potential. Even students with very challenging social contexts can formulate high expectations if they have verbal encouragement, opportunities for vicarious learning, and step-by-step mastery experiences related to their educational goals (Bandura, 1977). SCCT highlights the role that positive outcome expectations have in helping students move from a learning experience to the formation of interests, goals, and actions, which equates to college aspirations and plans in this case (Lent et al., 1994). Parental involvement is another key ingredient in educational aspirations and can be dampened in situations where schools do not provide linguistically or culturally relevant avenues for participation (Delgado-Gaitan, 1991).

From the opposite perspective, the regression model identified students' value ratings (e.g., easy admissions standards or the option to live at home as 
important in choosing an academic institution) as associated with the decision to attend a 2-year college. However, the rationale behind those choices is not clear. The preference to live at home may be related to concerns about finances or to strong family loyalty and cultural values that emphasize collective living arrangements (Duran, 1983). The literature also reflects that Latino students may have the tendency to use open-door or unselective institutions (Fry, 2002).

Students may be underestimating their ability to compete in more selective institutions or following the advice of influential others who are seeing them as at risk as opposed to at potential (D. C. Locke, personal communication, April 5, 2012). The main point is that these decisions can and should be examined to see what influences the students are responding to, how accurate their information sources are, and what perceptions are limiting them unnecessarily. The SCCT model shows that, prior to identifying a choice factor, students have likely engaged in learning opportunities and drawn conclusions about what types of educational outcomes they could expect. Thus, some corrective learning experiences might allow students to reconsider options they had foreclosed or evaluate their cognitive attributions (e.g., need easy admissions standards). The disempowering influence of structural racism and classism is important to identify and dispute if it has an impact on a student's choices. Counselors are encouraged to balance awareness of the economic or cultural influences on a student's decision making with appropriate and respectful encouragement to pursue their educational goals (Valadez, 2008).

In terms of SCCT, counselors may consider targeting a college choice intervention for students with high educational aspirations in the following ways: (a) inquire about students' academic and personal learning experiences and how those experiences have shaped their beliefs and expectations regarding education, (b) encourage discussion with parents and the formation or maintenance of high future aspirations, and (c) create step-by-step goals and action plans around college choice and access. The presence of barriers in the school or family context should be noted and addressed when possible. It is encouraging to view results that point to more malleable factors where counseling and educational development interventions could make an impact, as opposed to demographic explanations for college choice. An improved social-cognitive understanding of reasons associated with particular educational choices could help promote better outcomes wherever students are in their pathway to a degree.

This research was conducted with extant data, and, thus, limitations include the inability to create or modify variables of interest. Only main effects were tested, not interactions or mediated relationships that could exist. Public-level ELS:2002 data did not include identifying information about national origins within the panethnic Latino group, nor did it include geographic location 
of the schools. Thus, potential differences due to these factors could not be explored. Future research could include a qualitative exploration of reasons for Latinos to attend 2-year versus 4-year colleges, perhaps including a social network analysis.

\section{references}

Adams, R., \& Wu, M. (Eds.). (2002). PISA 2000 technical report. Paris, France: Organisation for Economic Co-Operation and Development.

Adelman, C. (2006). The toolbox revisited: Paths to degree completion from high school through college. Washington, DC: U.S. Department of Education.

Allison, P. D. (2002). Missing data. Thousand Oaks, CA: Sage.

American Institutes for Research. (n.d.). AM statistical software [Computer software]. Retrieved from http://am.air.org

Aud, S., Fox, M., \& Kewal Ramani, A. (2010). Status and trends in the education of racial and ethnic groups. Washington, DC: U.S. Department of Education.

Bailey, T. R., Jenkins, D., \& Leinbach, D. T. (2005). Community college low-income and minority student completion study: Descriptive statistics from the 1992 high school cohort. New York, NY: Community College Research Center.

Baker, T. L., \& Vélez, W. (1996). Access to and opportunity in postsecondary education in the United States: A review. Sociology of Education, 69, 82-101.

Bandura, A. (1977). Self-efficacy: Toward a unifying theory of behavioral change. Psychological Review, 84, 191-215. doi:10.1037/0033-295X.84.2.191

Behnke, A. O., Piercy, K. W., \& Diversi, M. (2004). Educational and occupational aspirations of Latino youth and their parents. Hispanic Journal of Behavioral Sciences, 26, 16-35. doi:10.1177/0739986303262329

Bohon, S. A., Johnson, M. K., \& Gorman, B. K. (2006). College aspirations and expectations among Latino adolescents in the United States. Social Problems, 53, 207-225. doi:10.1525/ sp.2006.53.2.207

Bohon, S. A., Macpherson, H., \& Atiles, J. H. (2005). Educational barriers for new Latinos in Georgia. Journal of Latinos and Education, 4, 43-58. doi:10.1207/s1532771xjle0401_4

Ceja, M. (2004). Chicana college aspirations and the role of parents: Developing educational resiliency. Journal of Hispanic Higher Education, 3, 338-362. doi:10.1177/1538192704268428

Contreras, F. E. (2005). Access, achievement, and social capital: Standardized exams and the Latino college-bound population. Journal of Hispanic Higher Education, 4, 197-214. doi:10.1177/1538192705276546

Delgado-Gaitan, C. (1991). Involving parents in the schools: A process of empowerment. American Journal of Education, 100, 20-46. doi:10.1086/444003

Duran, R. P. (1983). Hispanics' education and background: Predictors of college achievement. New York, NY: College Board Publications.

Flores, L. Y., Navarro, R. L., \& DeWitz, S. J. (2008). Mexican American high school students' postsecondary educational goals: Applying social cognitive career theory. Journal of Career Assessment, 16, 489-501. doi:10.1177/1069072708318905

Flores, L. Y., \& O'Brien, K. M. (2002). The career development of Mexican American adolescent women: A test of social cognitive career theory. Journal of Counseling Psychology, 49, 14-27. doi:10.1037/0022-0167.49.1.14

Flores, L. Y., Ojeda, L., Huang, Y.-P., Gee, D., \& Lee, S. (2006). The relation of acculturation, problem-solving appraisal, and career decision-making self-efficacy to Mexican American high school students' educational goals. Journal of Counseling Psychology, 53, 260-266. doi:10.1037/00220167.53 .2 .260

Fry, R. (2002). Latinos in higher education: Many enroll, too few graduate. Washington, DC: Pew Hispanic Center.

Fry, R., \& Passel, J. (2009). Latino children: A majority are US-born offspring of immigrants. Washington, DC: Pew Hispanic Center. 
Gibbons, M. M., \& Borders, L. D. (2010). Prospective first-generation college students: A social-cognitive perspective. The Career Development Quarterly, 58, 194-208. doi:10.1002/j.2161-0045.2010.tb00186.x

Goldsmith, P. A. (2004). Schools' racial mix, students' optimism, and the BlackWhite and Latino-White achievement gaps. Sociology of Education, 77, 121-147. doi:10.1177/003804070407700202

Gonzalez, A., \& Hilmer, M. J. (2006). The role of 2-year colleges in the improving situation of Hispanic postsecondary education. Economics of Education Review, 25, 249-257.

Goodman, R. D., \& West-Olatunji, C. A. (2010). Educational hegemony, traumatic stress, and African American and Latino American students. Journal of Multicultural Counseling and Development, 38, 176-186. doi:10.1002/j.2161-1912.2010.tb00125.x

Gushue, G. V., Clarke, C. P., Pantzer, K. M., \& Scanlan, K. R. L. (2006). Self-efficacy, perceptions of barriers, vocational identity, and the career exploration behavior of Latino/a high school students. The Career Development Quarterly, 54, 307-317. doi:10.1002/j.2161-0045.2006.tb00196.x

Hagy, A. P., \& Staniec, J. F. O. (2002). Immigrant status, race, and institutional choice in higher education. Economics of Education Review, 21, 381-392.

Hurtado, S., Inkelas, K. K., Briggs, C., \& Rhee, B.-S. (1997). Differences in college access and college choice among racial/ethnic groups: Identifying continuing barriers. Research in Higher Education, 38, 43-75.

Ingels, S. J., Pratt, D. J., Rogers, J. E., Siegel, P. H., Stutts, E. S., \& Owings, J. A. (2004). Education Longitudinal Study of 2002: Base year data file user's manual. Washington, DC: U.S. Department of Education.

Kao, G., \& Tienda, M. (1998). Educational aspirations of minority youth. American Journal of Education, 106, 349-384. doi:10.1086/444188

Kurlaender, M. (2006). Choosing community college: Factors affecting Latino college choice. New Directions for Community Colleges, Issue No. 133, 7-16. doi:10.1002/cc.223

Lent, R. W., Brown, S. D., \& Hackett, G. (1994). Toward a unifying social cognitive theory of career and academic interest, choice, and performance. Journal of Vocational Behavior, 45, 79-122. doi:10.1006/jvbe.1994.1027

Llagas, C., \& Snyder, T. D. (2003). Status and trends in the education of Hispanics. Washington, DC: National Center for Educational Statistics.

McDonough, P. M., \& Nunez, A. M. (2007). Bourdieu's sociology of education: Identifying persistent inequality, unmasking domination, and fighting social reproduction. In C. Torres \& A. Teodoro (Eds.), Critique and utopia: New developments in the sociology of education in the 21st century (pp. 139-154). Lanham, MD: Rowan \& Littlefield.

National Center for Education Statistics. (n.d.-a). Education Longitudinal Study of 2002 (ELS:2002). Retrieved from http://nces.ed.gov/surveys/els2002/

National Center for Education Statistics. (n.d.-b). National Education Longitudinal Study of 1988 (NELS:88). Retrieved from http://nces.ed.gov/surveys/nels88/

O'Connor, N. (2009). Hispanic origin, socio-economic status, and community college enrollment. Journal of Higher Education, 80, 121-145.

Ojeda, L., \& Flores, L. Y. (2008). The influence of gender, generation level, parent's education level, and perceived barriers on the educational aspirations of Mexican American high school students. The Career Development Quarterly, 57, 84-95. doi:10.1002/j.2161-0045.2008.tb00168.x

Pampel, F. C. (2000). Logistic regression: A primer. Thousand Oaks, CA: Sage.

Perez, P. A. (2010). College choice process of Latino undocumented students: Implications for recruitment and retention. Journal of College Admission, Issue No. 206, 21-25.

Perez, P. A., \& McDonough, P. M. (2008). Understanding Latina and Latino college choice. Journal of Hispanic Higher Education, 7, 249-265. doi:10.1177/1538192708317620

Perna, L. (2005). The benefits of higher education: Sex, racial/ethnic, and socioeconomic group differences. The Review of Higher Education, 29, 23-52. doi:10.1353/rhe.2005.0073

Person, A. E., \& Rosenbaum, J. E. (2006). Chain enrollment and college enclaves: Benefits and drawbacks of Latino college students' enrollment decisions. New Directions for Community Colleges, Issue No. 133, 51-60. doi:10.1002/cc.227

Plunkett, S. W., \& Bámaca-Gómez, M. Y. (2003). The relationship between parenting, acculturation, and adolescent academics in Mexican-origin immigrant families in Los Angeles. Hispanic Journal of Behavioral Sciences, 25, 222-239. doi:10.1177/0739986303025002005 
St-Hilaire, A. (2002). The social adaptation of children of Mexican immigrants: Educational aspirations beyond junior high school. Social Science Quarterly, 83, 1026-1043. doi:10.1111/15406237.00131

Suarez, A. L. (2003). Forward transfer: Strengthening the educational pipeline for Latino community college students. Community College Journal of Research and Practice, 27, 95-117.

Swail, W. S., Cabrera, A. F., \& Lee, C. (2004). Latino youth and the pathway to college. Washington, DC: Pew Hispanic Center.

U.S. Census Bureau. (2011). The 2011 statistical abstract: Income, expenditures, poverty, Eॄ wealth. Retrieved from http://www.census.gov/compendia/statab/cats/income_expenditures_poverty_wealth.html

Valadez, J. R. (2008). Shaping the educational decisions of Mexican immigrant high school students. American Educational Research Journal, 45, 834-860. doi:10.3102/0002831208320244

Zarate, M. E. (2007). Understanding Latino parental involvement in education: Perceptions, expectations, and recommendations. Los Angeles, CA: Tomás Rivera Policy Institute. 